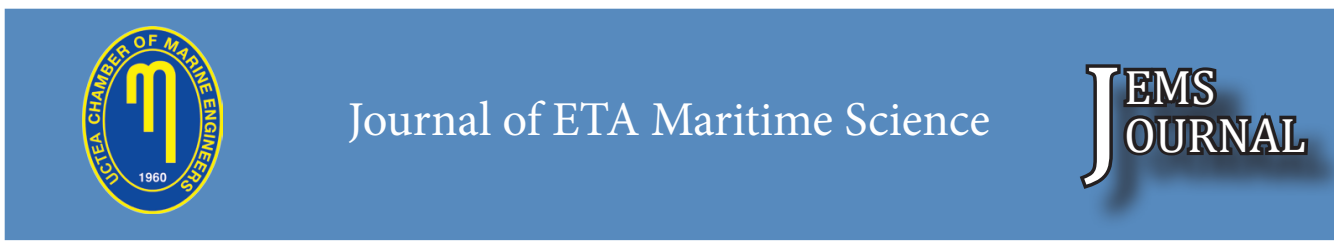

Corresponding Author: Duygu YILDIRIM PEKȘEN

\title{
Application of Alternative Maritime Power (AMP) Supply to Cruise Port
}

\section{Duygu YILDIRIM PEKȘEN ${ }^{1}$, Güler ALKAN ${ }^{2}$}

${ }^{1}$ Yalova University, Department of Maritime and Port Management, Turkey

${ }^{2}$ Iskenderun Technical University, Barbaros Hayrettin Ship Building and Maritime Faculty, Turkey duygu.yildirim@yalova.edu.tr; ORCID ID: https://orcid.org/0000-0002-7245-5114 guler.alkan@iste.edu.tr; ORCID ID: https://orcid.org/0000-0001-6809-0784

\begin{abstract}
The International Maritime Organization, the European Union Council and the US government force ship owners to take necessary measures through international conventions and national legislation to minimize ship-based emissions which damage to the environment and has reached a serious level. Thus, ship operators began to turn towards alternative technologies and fuels that reduce emissions to ensure the maritime trade smoothly. On the other hand, some port operators has started to supply alternative maritime power (AMP) which is electricity from city grid line to the ships at the berth. It is a fact that $A M P$ is one of the best emission reduction alternative technologies for ships during berthing period. This kind of ports providing AMP will be compulsory choice for many ship operators who still use fossil fuel-powered engines in their ships and cannot meet the emission limit requirements at ports, also these ports will contribute to the environmental protection.
\end{abstract}

In this study, AMP application will be examined for the Ege Ports in Kuşadası. Purpose of the study is to calculate the amount of emissions and external costs and to compare with marine gas oil (MGO) when the AMP system is applied to a port. According to comparison of AMP technology with MGO (0.1\%S); total air pollutant is reduced by $94 \%$ via decreasing SO2 23\%, NOx 97\%, PM 88\%, CO 99\%, VOC 64\%. On the other hand, it is estimated that total released greenhouse gases are minimized by $41 \%$ via decreasing CO2 41\%, N2O 85\% and CH4 81\%. Finally, total emission reduction was about 43\%. The economic and environmental benefits to the port hinterland and its country has been estimated by finding external cost. Total externality cost of MGO for human health, ecosystem quality and climate change was found as about Euro 3 million while Euro 0,4 million occured from AMP.

Keywords: Cruise Port, Emission Reduction, Alternative Technology, AMP.

\section{Kruvaziyer Limanına Alternatif Güç Kaynağı (AMP)'nin Uygulanması}

\section{$\ddot{O} z$}

Uluslararası Denizcilik Örgütü (IMO), Avrupa Birliği Konseyi ve ABD hükümeti, gemi sahiplerine çevreye zarar veren ve ciddi bir düzeye ulaşan emisyonları en aza indirgemek için uluslararası sözleșmeler ve ulusal mevzuat ile gerekli önlemleri almaya zorlamaktadır. Böylece gemi sahipleri ve gemi işletmecileri, deniz ticaretini sorunsuz bir şekilde sağlamak için emisyonları azaltan alternatif teknolojilere ve yakıtlara yönelmişlerdir. Öte yandan, bazı liman işletmecileri, şehir şebekesi hattından rıhtımdaki This paper was presented at 23rd International Conference on Researches in Science and Technology (ICRST), 12-13 Oct 2017, Dubai and only abstract will be published. 
gemilere ve diğer birçok hizmete alternatif olan alternatif deniz gücü (AMP) sağlamaya başladılar. AMP'nin yanaşma safhasında gemiler için en iyi emisyon azaltma alternatif teknolojilerinden biri olduğu bir gerçektir. AMP alternatifi sunun bu tip limanlar, gemilerinde fosil yakıtla çalışan motorları kullanan ve limanlardaki emisyon sınırlama gereksinimlerini karşılayamayan birçok gemi operatörü için zorunlu bir seçim olacaktır. Ayrıca bu limanlar da çevre korumaya katkıda bulunacaktır.

Bu çalışmada, Kuşadası'ndaki Ege Limanları için rıhtımdaki gemiler için emisyon azaltıcı teknoloji olarak AMP uygulaması incelenecektir. Çalışmanın amacı, AMP sistemi bir limana uygulandı̆̆ında emisyon ve dış maliyetlerin miktarını hesaplamak ve deniz yakıtı (MGO) karșılaștırmaktır. AMP teknolojisinin MGO ile karșllaștırılmasına göre (\% 0,1 S); Toplam hava kirliliği\% 94 azalırken SO2\% 23, NOx\% 97, PM\% 88, CO\% 99, VOC\% 64 azaltılmıștır. Öte yandan, toplam salınan sera gazlarının\% 41 azalarak CO2\% 41, N2O\% 85 ve CH4\% 81 oranında azaldığı tahmin edilmektedir. Son olarak, toplam emisyon azaltımı yaklaşık\% 43 olmuştur. Ayrıca liman iç bölgelerine ve ülkesine ekonomik ve çevresel faydalar, maliyet dışı maliyetler kullanılarak tahmin edilmiştir. MGO'nun insan sağlığı, ekosistem kalitesi ve iklim değişikliği için toplam dışsallık maliyeti yaklaşık 3 milyon Euro, AMP'den 0,4 milyon Euro olarak gerçekleşmiştir.

Anahtar Kelimeler: Kruvaziyer Limanı, Emisyon Azaltımı, Alternatif Teknoloji, AMP.

\section{Introduction}

Ships at berth need electricity for routine operations such as communications, lighting, heating or cooling, ventilation, and using onboard devices. This electricity is produced generally from generators (auxiliary engines) by the combustion of marine fuels. Required electricity power depends on the ship's type, size, and berthing time. Especially the cruise ship needs a considerable amount of electricity at berth because of its hotel concept which suggest that all rooms in every deck should be heated or cooled immediately after each client's order. It means giant air conditioners always have to work. For this reason, cruise ships cause much emission than other ships while staying at the port. During the berthing period, the ship turns off the main engine but she has to sustain runing its auxiliary engines and boilers to produce electricity. Unfortunately, combustion of marine fuel causes air emissions which damage the environment, air quality, human health, and cultural heritage. Thus, cruise ports can be called "bad neighbors" in terms of air quality and human health [1].

Because of increasing air pollution from ships worldwide, major actors (as
International Maritime Organization (IMO), the European Union Council and the US government) in maritime sector have taken some measures through international conventions and national legislations to minimize and limit ship-based emissions. Therefore, ships have to use clean fuel or technology in order to continue marine trade. Many options for emission reduction target are offered to ship owners or port operators such as cleaner fuel, waterbased fuel treatment, or clean engine after combustion treatment while the ship is at berthing mode. Also one of the emission reduction alternatives for ships is using alternative maritime power (AMP), which means having electricity from the national grid in place of producing it by ship auxiliary engines.

Hence, AMP is a beneficial solution for cruise ports to considerably reduce shipcaused emissions. Ege Ports is one of the most important ports in Turkey for cruise tourism. Clean and beautiful sandbanks with many historical places in Kuşadası attract the tourists and this port has been preferred by the cruise ship operators. As a result, it was estimated that the amount of emissions $\left(\mathrm{SO}_{2}, \mathrm{NO}_{\mathrm{x}}, \mathrm{PM}, \mathrm{CO}, \mathrm{VOC}, \mathrm{CO}_{2}, \mathrm{~N}_{2} \mathrm{O}\right.$, $\mathrm{CH}_{4}$ ) was roughly 13,000 tons from the 506 
ships that visited Kuşadası port in 2015, [2]. We analyzed how effective this solution is to reduce ship-based emissions at this cruise port.

\subsection{Literature Review}

Chang and Wang (2012), who studied on Kaohsiung port, have deduced that if AMP were used instead of fuel at berth period, $\mathrm{CO}_{2}$ and Particulate Matter (PM) emissions could be reduced by $57 \%$ and $39 \%$, respectively [3].

Andria et al. (2013) found that using AMP could reduce ship-based emissions at berth $94 \%$ for $\mathrm{NO}_{\mathrm{x},} 42 \%$ for $\mathrm{CO}_{2}$ and $90 \%$ for PM emissions [4].

Ballini (2013) calculated emissions amount for the Port of Copenhagen. The total $\mathrm{SO}_{2}, \mathrm{NO}_{\mathrm{x},} \mathrm{PM}$ emissions from the 70 cruise vessels (308 calls) in the summer season of 2012 were approximately 9 tons, 408 tons, 4 tons respectively. If all the ships used AMP instead of MGO, the difference of emissions of $\mathrm{SO}_{2}, \mathrm{NO}_{\mathrm{x}}, \mathrm{PM}$ and $\mathrm{CO}_{2}$ release would be less than 65\%, 98\%, 90\%, 34\% respectively, and also the differences of external costs would be same rates [5].

According to Zis et al. (2014), the provision of AMP for ships at berth can lead to reductions of $\mathrm{CO}_{2}, \mathrm{SO}_{2}, \mathrm{NO}_{\mathrm{x}}$ and $\mathrm{BC}$ emissions. The rate of reduction is $48-70 \%$, 3-60\%, 40-60\%, and 57-70\% respectively [6].

Yustiano (2014) analyzed the Port of Tanjung Perak. As a result, the total amount of emission from passenger vessels were 4,785 tons, which included 122.27 tons $\left(\mathrm{NO}_{\mathrm{x}}\right), 37.83$ tons $\left(\mathrm{SO}_{2}\right), 2.6$ tons (PM10), 2.1 tons (PM 2.5), 9.7 tons (CO), 4,601 tons $\left(\mathrm{CO}_{2}, 3.5\right.$ Ton (HC), 7 tons (VOC). The externality cost of the total amount of passenger ship emissions was $\$ 700,465$ [7].

The result of study of Tseng and Pilcher (2015) is that if the $60 \%$ of the total visiting ships at the Kaohsiung Port used the AMP, reduction of $\mathrm{NO}_{\mathrm{x}}$ and $\mathrm{CO}_{2}$ emissions would be 428 ton/y, 25,391 ton/y respectively and reduction of $\mathrm{NO}_{x}$ environmental cost 2,136,148 (US\$/year), of $\mathrm{CO}_{2}$ environmental cost 660,166 (US\$/ year) [8].

According to Environ Final Report (2015), the emissions reduction of HC, CO, $\mathrm{NO}_{\mathrm{x}}, \mathrm{PM}$ and $\mathrm{SO}_{\mathrm{x}}$ are respectively about $76 \%, 61 \%, 80 \%, 79 \%$ and $80 \%$ for the Port of San Francisco for cruise ships [9].

\subsection{Alternative Maritime Power}

Ships can shut down the auxiliary engine at berths and use the required power from national grid to reduce air emissions for meeting EU and IMO sulphur limits. This technology is known as 'alternative maritime power', 'cold ironing', 'shore-side power', 'high-voltage shore connections (HVSC) [10]. AMP technology has been used for a long time in the military fields so it is not a new technology. Nowadays it is very popular because of new regulations regarding emission from ships [1].

\section{Pros and cons:}

- AMP can decrease $\mathrm{SO}_{2}, \mathrm{NO}_{\mathrm{x}}, \mathrm{PM}, \mathrm{CO}, \mathrm{VOC}$, $\mathrm{CO}_{2}, \mathrm{~N}_{2} \mathrm{O}, \mathrm{CH}_{4}$ emissions considerably. Their amounts depend on sources of electricity power.

- This system eliminates noise and vibration from ships at the port area.

- Because of less emissions and noise, AMP affect air quality and human health positively [1].

- It requires a high capital cost.

- There is no standardized voltage, frequency and electric demands. Ships use different voltages $(6.6 \mathrm{kV}$ or 11.0 $\mathrm{kV}$ ) and ports in the world use different frequencies ( 50 or $60 \mathrm{~Hz}$ ).

- AMP only affects emissions amount while at berth not at voyage.

- Power requirements are various by ships type

- AMP needs spaces for on-board transformer. It may affect the weight restrictions of the ship [12]. 


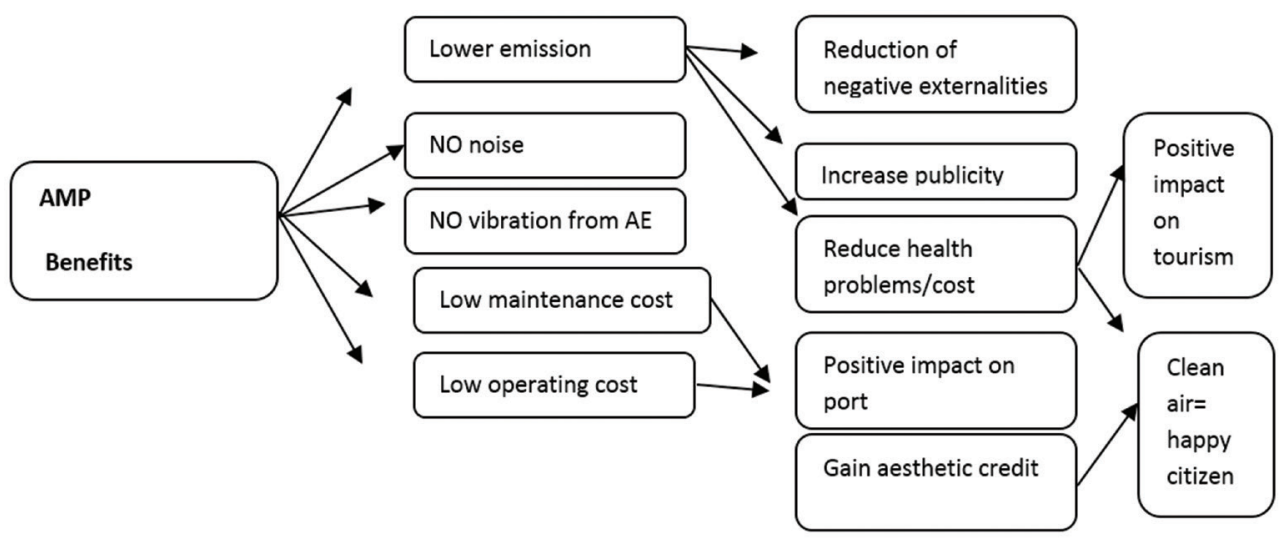

Figure 1. Alternative Maritime Power Benefits [11]

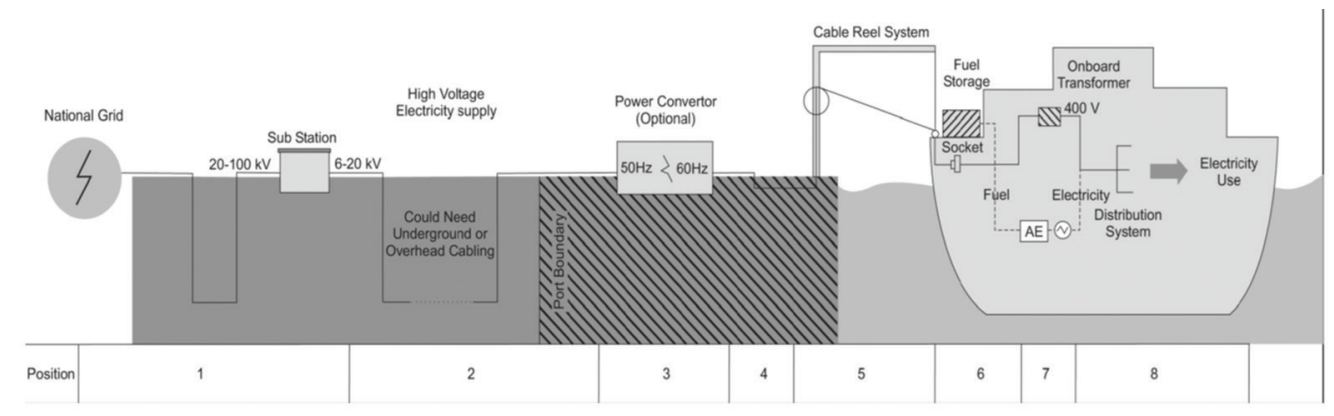

Figure 2. Alternative maritime power system [10]

Figure 1 summarizes the benefits and effects of AMP to air quality, citizens' health, and clean environment.

AMP system consists of three basic components:

1. Shore-side electrical system and infrastructure; a land-based power source, substation, transmission system, conduits, shore-side electrical vault, connectors and other components supply electricity to ship at berth.

2. Cable management system; in which cables, reel and connectors carry shoreside electric power to the ship.

3. Ship-side electrical system; retrofit of onboard electrical system is required for existing ship while the required system can be added when new ships are built. The ship using AMP needs a socket, transformer and distribution system [12].
ENTEC has summarized the abovementioned system comprehensively as seen Figure 2;

According to Figure 2, positions mean that;

1. The system needs a link to the national grid for carrying 20-100 kV power from a local substation.

2. Cables conduct the $6-20 \mathrm{kV}$ power that is converted in the substation to the port terminal.

3. Power is converted to 50 or $60 \mathrm{~Hz}$ which is required for ships

4. Electricity is distributed to the terminal.

5. The cable reel tower that is built on the berth with a cable reel, davit and frame can be used to prevent handling of high voltage cables. The davit and frame would be used to raise and lower the cables to the vessel by electromechanically powered and controlled. 
6. The ship needs a socket for connecting cable.

7. The ship needs an onboard transformer for transforming the high voltage electricity to $400 \mathrm{~V}$.

8. The electricity is then distributed around the ship, and the auxiliary engines are switched off [10].

\section{Material and Methods}

\subsection{Case Study and Data}

Ege Ports is located in Aegean Sea, western Turkey and is also a substantial cruise port for both Turkey and East Mediterranean Region.

Cruise ship operators prefer to visit this port because of the city's location, historical importance and beautiful coast, especially in the summer season. Table 1 summarized that how many ships and passengers have visited to 3 most important cruise ports in Turkey for last three years. Number of cruise ships reduced dramatically in 2016 in Turkey, especially in Istanbul. The security issue is the main reason of that. Hence, many cruise operators have removed Turkey's cruise ports from their port call list, especially after some terror attack in Istanbul. On the other hand, such adverse events have not impressed Kuşadası Ege Ports as much as the other Turkish ports. Factors that make Kuşadası so attractive for tourists are historical and sacred places such as Ephesus, Artemis Temple, Virgin Mary's House, St John's Basilica, Priene, Miletus, Didim, Claros, as well as the region's soft climate, virgin beaches, transparent seas and natural beauties. In addition, cruise operators prefer this city because of its high standard port with its infrastructure and service concept $[14,15]$. According to survey reports, especially American, British, Canadian, German, Spanish, French, Italian, Greek, South Korean and Dutch prefer to travel to this city [16].

In this study, ships visited Ege Ports
Table 1. The Number of Ships and Passengers of Turkey's Most Important Cruise Ports [13]

\begin{tabular}{|l|l|l|l|l|}
\hline $\begin{array}{l}\text { Cruise } \\
\text { Port }\end{array}$ & Year & 2014 & 2015 & 2016 \\
\hline \multirow{3}{*}{ Kuşadası } & $\begin{array}{l}\text { Number of } \\
\text { ships }\end{array}$ & 448 & 506 & 271 \\
\cline { 2 - 5 } & $\begin{array}{l}\text { Number of } \\
\text { passengers }\end{array}$ & 556,745 & 567,315 & 349,781 \\
\hline \multirow{3}{*}{ İtanbul } & $\begin{array}{l}\text { Number of } \\
\text { ships }\end{array}$ & 317 & 345 & 56 \\
\cline { 2 - 5 } & $\begin{array}{l}\text { Number of } \\
\text { passengers }\end{array}$ & 518,935 & 595,880 & 43,543 \\
\hline \multirow{2}{*}{ İmir } & $\begin{array}{l}\text { Number of } \\
\text { ships }\end{array}$ & 124 & 114 & 24 \\
\cline { 2 - 5 } & $\begin{array}{l}\text { Number of } \\
\text { passengers }\end{array}$ & 257,233 & 241,716 & 27,619 \\
\hline
\end{tabular}

Table 2. Information of ships berthing to Kuşadası Port between April and September 2015

\begin{tabular}{|l|l|l|l|}
\hline \multicolumn{4}{|c|}{ Ship Information } \\
\hline $\begin{array}{l}\text { Total number of } \\
\text { different ships }\end{array}$ & \multicolumn{2}{|l|}{62} \\
\hline $\begin{array}{l}\text { Total number of } \\
\text { berthing }\end{array}$ & \multicolumn{3}{|l|}{$385(76 \%)$} \\
\hline $\begin{array}{l}\text { Total berthing } \\
\text { hours }\end{array}$ & 4,190 hours \\
\hline $\begin{array}{l}\text { Average berthing } \\
\text { hours }\end{array}$ & 10.8 hours \\
\hline Dimension & Max & Min & Average \\
\hline & 125,366 & 1,206 & 45,094 \\
\hline GRT & 3,782 & 49 & 1,268 \\
\hline Passenger capacity & & \\
\hline
\end{tabular}

between April and September (summer season) in 2015 are analyzed as seen in Table 2. The average number of ships arriving in the summer is $76 \%$ of the total number of ships. The data about ships information regarding berthing time and GT were taken from the website of Kuşadası District Governorship, other information about ships and passenger capacity were taken from the website of marinetraffic. com and from their operators' websites $[17,18]$. 


\subsection{Estimation of Fuel Consumption}

Simonsen (2014) calculated the amount of fuel consumption of cruise ships to produce electric energy at berth. This fuel consumption was measured from cruise ships which visited Skagwey berth in 2008 and proportioned the number of passenger on board. By this rate, Simonsen found ' $k$ ' constant that states diesel oil consumption per passenger per GT per hour [19].

Formula;

$$
\begin{aligned}
& \mathrm{FC}_{\mathrm{bi}}=\mathrm{GT}^{*} \mathrm{k}^{*} \mathrm{~Pa}^{*} \mathrm{t}_{\mathrm{bi}} * 0.84 \\
& \mathrm{FC}_{\mathrm{b}}=\sum_{i=1}^{n} F C b i
\end{aligned}
$$

$\mathrm{FC}_{\mathrm{bi}}$ : fuel consumption at berth $(\mathrm{kg})$

GT: Gross Tonnage (GT)

$\mathrm{t}_{\mathrm{bi}}$ : i. voyage's berthing time (hr)

k: 0.0000106 (diesel oil consumption per

passenger per GT per hour)

(lt/Pa*GT*hr)

$\mathrm{Pa}$ : number of passenger

i: voyage number

$\mathrm{n}$ : number of voyage

*1 lt DO $=0.84 \mathrm{~kg} \mathrm{DO}$

\subsection{Estimation of Required Electric Energy}

After the calculation of fuel consumption by means of above formulas, required electric energy can be estimated with the assumption of ENTEC. Specific Fuel Consumption of Auxiliary Engine $\left(\mathrm{SFC}_{\mathrm{AE}}\right)$; [10]

$$
\mathrm{MCR}_{\mathrm{AE}}>800 \mathrm{~kW} \rightarrow 220 \mathrm{~g} / \mathrm{kWh}
$$$$
\mathrm{MCR}_{\mathrm{AE}}<800 \mathrm{~kW} \rightarrow 230 \mathrm{~g} / \mathrm{kWh}
$$

Cruise ships' auxiliary engine power is more than $800 \mathrm{~kW}$ in general so it is assumed that;

$$
220 \mathrm{~g} \mathrm{MGO}=1 \mathrm{kWh}
$$

\subsection{Estimation of Emission Amount}

The emission factor varies by fuel type, ship type, engine type and phase of cruising, maneuvering and berthing. According to EU Directive 2005/33/EC, the ships that approach to EU ports are required to use only marine fuel with a sulphur content not exceeding $0.1 \%$ by mass. This provision entered into force on 1 January 2010 with some exemptions in which the $0.1 \%$ sulphur cap if ships are berthed less than two hours. Therefore, as the emission factors, as shown in Table 3, emission factors of MGO fuel by $0.1 \%$ sulphur were used in this study. Table 3 presents average values of selected emission factors which also acquired from four different studies [20].

These emission factors in Table 4 were calculated by using data from Table 5-6. Table 5 indicates emission factors (g/kWh) that are caused by fuel type which are used for generating electricity by Argonne National Laboratory in 2012 for the US Department of Energy. 73,146.8 MW total installed power was produced in Turkey in 2015 by fuel type of which the rates are shown in Table 6. According to the rate of fuel type in 2015 and emission factors of these fuel types, average emission factors for 2015 were calculated as shown in Table 4.

\subsection{Estimation of External Cost of Ship Emission \\ Emission effects are causing expenditure} to countries affected by ship emissions. "A New Environmental Accounting Framework Using Externality Data and Input - Output Tools for Policy Analysis" (EXIOPOL) that was built up by European Union (EU) aims to define theoretical-mathematical concepts of linking environmental extensions (EE) to the framework Supply-and Use-Tables (SUT) for 43 countries (including Turkey) [23]. Table 7 shows that external cost of human health, ecosystem quality and climate change external for transport for Turkey.

Calculated emission from MGO and electricity obtained by above formulas will be used to estimate external cost for Turkey by the help of data of EXIOPOL project as shown in Table 7. 
Table 3. Emission Factors of 0.1\% MGO While Ship is Berthing [20]

\begin{tabular}{|l|l|l|l|l|l|l|l|l|}
\hline \multirow{2}{*}{ Factor } & \multicolumn{7}{|c|}{ Polluting Types } \\
\cline { 2 - 9 } & $\mathrm{CO}_{2}$ & $\mathrm{CH}_{4}$ & $\mathrm{~N}_{2} \mathrm{O}$ & $\mathrm{SO}_{2}$ & $\mathrm{NO}_{x}$ & $\mathrm{PM}$ & $\mathrm{CO}$ & VOC \\
\hline g/kg fuel & 3213.429 & 0.166 & 0.134 & 2.741 & 63.019 & 1.521 & 8.007 & 1.984 \\
\hline
\end{tabular}

Table 4. Emission Factors of Electricity Generation per kWh in Turkey for 2015

\begin{tabular}{|l|l|l|l|l|l|l|l|l|l|}
\hline \multirow{2}{*}{ Factor } & \multicolumn{7}{|c|}{ Polluting Types } \\
\cline { 2 - 10 } & $\mathrm{CO}_{2}$ & $\mathrm{CH}_{4}$ & $\mathrm{~N}_{2} 0$ & $\mathrm{SO}_{2}$ & $\mathrm{NO}_{\mathrm{x}}$ & $\mathrm{PM}_{10}$ & $\mathrm{PM}_{25}$ & $\mathrm{CO}$ & VOC \\
\hline $\mathrm{g} / \mathrm{kWh}$ & 415 & 0.00700 & 0.00430 & 0.46186 & 0.40998 & 0.03392 & 0.04688 & 0.01218 & 0.15600 \\
\hline
\end{tabular}

Table 5. Emission Factors of Fuels in Generation of Electricity [21]

\begin{tabular}{|l|l|l|l|l|l|l|l|}
\hline $\begin{array}{l}\text { Emission } \\
\text { Factors } \\
(\mathrm{g} / \mathrm{kWh})\end{array}$ & \multicolumn{3}{|c|}{ Coal } & Natural Gas & $\begin{array}{l}\text { Geothermal } \\
\text { Nuclear } \\
\text { Hydraulic } \\
\text { Wind }\end{array}$ & Fuel Oil & Diesel \\
\cline { 2 - 8 } & Lignite & bituminous & $\begin{array}{l}\text { sub } \\
\text { bituminous }\end{array}$ & & 0.2 & & \\
\hline $\mathrm{CH}_{2}$ & 901.8 & 829.1 & 864.2 & 631.2 & 0 & 791.1 & 1179.3 \\
\hline $\mathrm{N}_{2} \mathrm{O}$ & 0.01161 & 0.01078 & 0.01148 & 0.01253 & 0 & 0.03058 & 0.05075 \\
\hline $\mathrm{NO}_{\mathrm{x}}$ & 0.01723 & 0.01583 & 0.01711 & 0.00143 & 0 & 0.0059 & 0.01018 \\
\hline $\mathrm{SO}_{\mathrm{x}}$ & 0.75184 & 0.839622 & 0.77258 & 0.83724 & 0 & 1.35301 & 1.79151 \\
\hline $\mathrm{PM}_{10}$ & 1.88299 & 2.43893 & 1.48558 & 0.00449 & 0 & 3.29910 & 4.81600 \\
\hline $\mathrm{PM}_{2.5}$ & 0.13151 & 0.11939 & 0.03684 & 0.03528 & 0 & 0.13979 & 0.11794 \\
\hline $\mathrm{VOC}$ & 0.01447 & 0.00878 & 0.010205 & 0.02714 & 0 & 0.02555 & 0.03897 \\
\hline $\mathrm{CO}$ & 0.125635 & 0.10018 & 0.112125 & 0.40760 & 0 & 0.02557 & 0.25638 \\
\hline
\end{tabular}

Table 6. Distribution of Total Installed Power by Type of Energy Source for Turkey in 2015 [22]

\begin{tabular}{|c|c|c|c|c|c|c|c|c|c|c|c|c|c|}
\hline \multirow[t]{2}{*}{ Year } & \multicolumn{3}{|c|}{ Coal } & \multirow{2}{*}{$\begin{array}{l}\text { Natural } \\
\text { Gas }\end{array}$} & \multirow{2}{*}{$\begin{array}{l}\text { Geo } \\
\text { thermal }\end{array}$} & \multirow{2}{*}{$\begin{array}{l}\text { Fuel } \\
\text { Oil }\end{array}$} & \multirow[t]{2}{*}{ Diesel } & \multirow[t]{2}{*}{ Sun } & \multirow[t]{2}{*}{ Other } & \multirow{2}{*}{$\begin{array}{l}\text { Biogas- } \\
\text { Waste }\end{array}$} & \multirow[t]{2}{*}{ Hydraulic } & \multirow[t]{2}{*}{ Wind } & \multirow[t]{2}{*}{ MW } \\
\hline & lignite & $\begin{array}{l}\text { Bitu- } \\
\text { Minous }\end{array}$ & $\begin{array}{l}\text { subbitu } \\
\text { minous }\end{array}$ & & & & & & & & & & \\
\hline 2015 & 9330.5 & 755 & 6064 & 24906 & 624 & 440 & 1 & 249 & 43.6 & 362.4 & 25867.8 & 4503 & 73147 \\
\hline
\end{tabular}

Table 7. External Cost Factors per ton for Transport (Euro/ton) [23]

\begin{tabular}{|l|l|l|l|l|}
\hline Pollutant & $\begin{array}{l}\text { Human } \\
\text { Health }\end{array}$ & $\begin{array}{l}\text { Ecosystem } \\
\text { Quality }\end{array}$ & $\begin{array}{l}\text { Climate } \\
\text { Change }\end{array}$ & Total \\
\hline $\mathrm{SO}_{2}$ & 6,300 & 200 & 0 & 6,500 \\
\hline $\mathrm{NO}_{\mathrm{x}}$ & 5,700 & 1,000 & 0 & 6,700 \\
\hline $\mathrm{PM}$ & 350,000 & 0 & 0 & 350,000 \\
\hline $\mathrm{CO}$ & 29 & 0 & 33 & 62 \\
\hline $\mathrm{VOC}$ & 940 & -70 & 0 & 870 \\
\hline $\mathrm{CO}_{2}$ & 0 & 0 & 21 & 21 \\
\hline $\mathrm{N}_{2} \mathrm{O}$ & 0 & 0 & 6,200 & 6,200 \\
\hline $\mathrm{CH}_{4}$ & 0.51 & 0 & 480 & 480.51 \\
\hline
\end{tabular}




\section{Result and Discussion}

The total amount of MGO consumed by all cruise ships approached Ege Ports in 2015 was calculated 3,076.642 tons with formula 1 and 2, summarized in Table 8 [2]. Assuming that auxiliary engine of cruise ships was bigger than the $800 \mathrm{~kW}$, the fuel consumption has converted to $13,984,738.11 \mathrm{kWh}$ by using equation 3 , and that figure shows required electric energy amount. In addition, emission amounts caused by producing this electric energy were calculated in Table 8, and the emission reduction rates were calculated according to MGO (0.1\%).

The ship emission reduction potential of AMP technology is clearly visible in Table 8 and Figure 3. It is seen that total air pollutant is reduced by $94 \%$ by decreasing $\mathrm{SO}_{2} 23 \%$, $\mathrm{NO}_{\mathrm{x}}$ 97\%, PM 88\%, C0 99\%, VOC 64\%. On the other hand, it is estimated that total greenhouse gas decreased by $41 \%$ by decreasing by $\mathrm{CO}_{2} 41 \%$, $\mathrm{N}_{2} \mathrm{O} 85 \%$ and $\mathrm{CH}_{4} 81 \%$. Finally, total emission reduction is about $43 \%$.

Figure 3 shows that emission amount of MGO and AMP, and clearly seen that using AMP is better than MGO.

Table 8. Comparisons of Emission Amount

\begin{tabular}{|l|l|l|l|l|l|l|l|l|l|}
\hline $\begin{array}{l}\text { Emission amount } \\
(\mathrm{kg})\end{array}$ & $\mathrm{SO}_{2}$ & $\mathrm{NO}_{\mathrm{x}}$ & $\mathrm{PM}$ & $\mathrm{CO}$ & $\mathrm{VOC}$ & $\mathrm{CO}_{2}$ & $\mathrm{~N}_{2} \mathrm{O}$ & $\mathrm{CH}_{4}$ & $\begin{array}{l}\text { Total } \\
\text { Emission }\end{array}$ \\
\hline MGO & 8432 & 193888 & 4680 & 24634 & 6104 & 9886571 & 412 & 509 & $10,125,230$ \\
\hline AMP & 6459 & 5733 & 565 & 170 & 2182 & 5803666 & 60 & 98 & $5,818,934$ \\
\hline Reduction (\%) & 0,23 & 0,97 & 0,88 & 0,99 & 0,64 & 0,41 & 0,85 & 0,81 & 0,43 \\
\hline
\end{tabular}
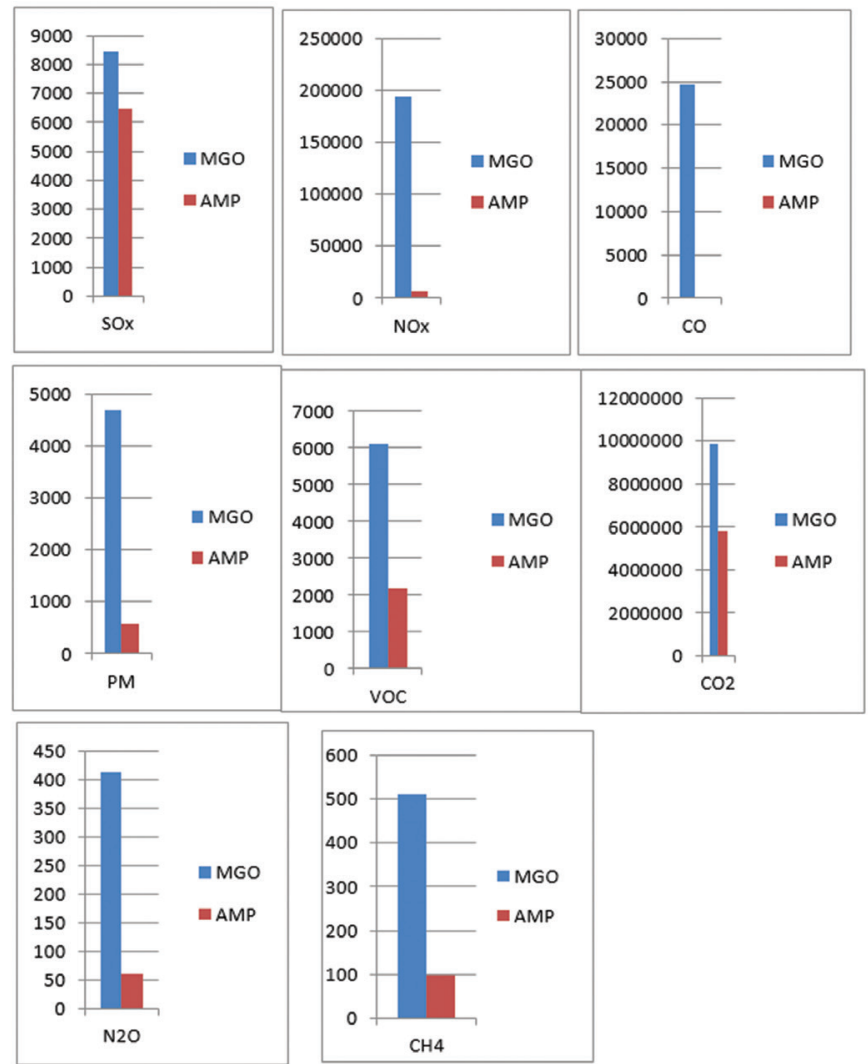

Figure 3. Comparisons of Emission Amount of MGO and AMP 
Table 9. Comparison of External Cost (Euro)

\begin{tabular}{|l|l|l|l|l|l|l|l|l|}
\hline $\begin{array}{l}\text { Emission } \\
\text { Type }\end{array}$ & \multicolumn{9}{|l|}{ MGO } \\
\hline & $\begin{array}{l}\text { Human } \\
\text { Health }\end{array}$ & $\begin{array}{l}\text { Ecosystem } \\
\text { Quality }\end{array}$ & $\begin{array}{l}\text { Climate } \\
\text { Change }\end{array}$ & Total & $\begin{array}{l}\text { Human } \\
\text { Health }\end{array}$ & $\begin{array}{l}\text { Ecosystem } \\
\text { Quality }\end{array}$ & $\begin{array}{l}\text { Climate } \\
\text { Change }\end{array}$ & Total \\
\hline SO2 & 53,120 & 1,686 & 0 & 54,806 & 40,692 & 1,292 & 0 & 41,983 \\
\hline NOx & $1,105,163$ & 193,888 & 0 & $1,299,051$ & 3,2681 & 5,733 & 0 & 38,414 \\
\hline PM & $1,638,120$ & 0 & 0 & $1,638,120$ & 197,744 & 0 & 0 & 197,744 \\
\hline CO & 714 & 0 & 813 & 1,527 & 5 & 0 & 6 & 11 \\
\hline VOC & 5,738 & -427 & 0 & 5,311 & 2,051 & -153 & 0 & 1,898 \\
\hline CO2 & 0 & 0 & 207,618 & 207,618 & 0 & 0 & 121,877 & 121,877 \\
\hline N20 & 0 & 0 & 2,553 & 2,553 & 0 & 0 & 373 & 373 \\
\hline CH4 & 0 & 0 & 244 & 245 & 0 & 0 & 47 & 47 \\
\hline Total & $\mathbf{2 , 8 0 2 , 8 5 5}$ & $\mathbf{1 9 5 , 1 4 7}$ & $\mathbf{2 1 1 , 2 2 8}$ & $\mathbf{3 , 2 0 9 , 2 3 0}$ & $\mathbf{2 7 3 , 1 7 2}$ & $\mathbf{6 , 8 7 3}$ & $\mathbf{1 2 2 , 3 0 2}$ & $\mathbf{4 0 2 , 3 4 7}$ \\
\hline
\end{tabular}
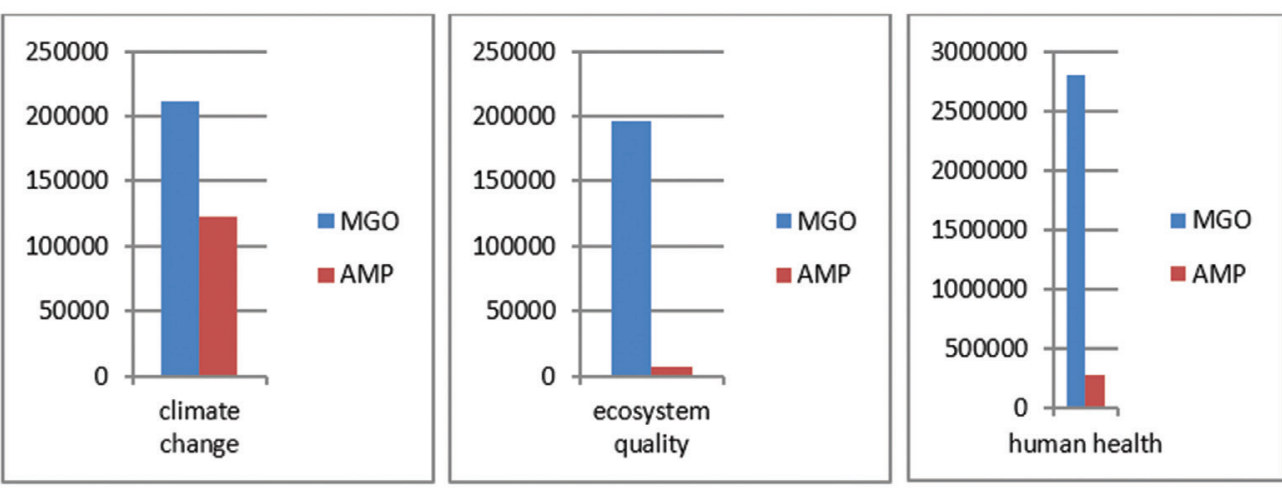

Figure 4. Comparisons of External Cost of MGO and AMP (Euro)

The external cost on human health, ecosystem quality and climate change in Table 9 is calculated by multiplying data in Table 7 and by using MGO emission amount and total required electric energy amount as above. AMP also reduces $\mathrm{PM}$ and $\mathrm{NO}_{\mathrm{x}}$ emission remarkably and also affect human health positively.

As it is known well, $\mathrm{NO}_{\mathrm{x}}$ gases damage ecosystem quality too. The effect of AMP on NOx emissions of berthed ships is to stop negative impacts on ecosystem quality by resetting a great amount of NOx emissions. In addition to $\mathrm{NO}_{\mathrm{x}}, \mathrm{CO}_{2}$ also affects climate change considerably and AMP even reduces this emission about $40 \%$ and its bad impact on climate change. In conclusion; external cost of AMP has been estimated about Euro 402,347 whereas external cost of MGO has been found about Euro 3,209,230. Figure 4 summarizes that external costs of MGO and AMP for climate change, ecosystem quality and human health. The difference is so high on ecosystem quality and human health.

Table 10 shows that emission reduction rates between different ports through the world if the vessel uses the alternative maritime power at berth instead of MGO. One of the important issue is that electric power is produced from different sources. If the electric power is obtained from a cleaner source, the emission reduction rate will be higher. 
Table 10. Comparison of Emission Reduction Rates

\begin{tabular}{|l|c|c|c|c|c|c|}
\hline \multicolumn{1}{|c|}{ Emission Types } & $\mathrm{CO}_{2}$ & $\mathrm{PM}$ & $\mathrm{NO}_{\mathrm{x}}$ & $\mathrm{SO}_{2}$ & $\mathrm{CO}$ & \\
\hline Port of Kaohsiung & $57 \%$ & $39 \%$ & & & & {$[3]$} \\
\hline Port of Taranto & $42 \%$ & $90 \%$ & $94 \%$ & & {$[4]$} \\
\hline Port of Copenhagen (cruise ships) & $34 \%$ & $90 \%$ & $98 \%$ & $65 \%$ & & {$[5]$} \\
\hline Port of San Francisco (cruise ships) & & $79 \%$ & $80 \%$ & $80 \%$ & $62 \%$ & {$[9]$} \\
\hline Port of Ege Ports (cruise ships) & $41 \%$ & $88 \%$ & $97 \%$ & $23 \%$ & $99 \%$ & Authors \\
\hline
\end{tabular}

\section{Conclusion}

Limitations on the amount of emissions have encouraged port operators as well as shipowners should find solutions. After the implementation of the max $0.1 \% \mathrm{~S}$ restriction implemented at the ports after 2012, all ships are required to pass to clean fuel or alternative emission abatement technology when they arrive ports. The only alternative technology for port operators is seen as AMP. Innovative pursuits in the increasing competitive environment of the port industry have led some ports to use AMP. If the vessels arriving at these ports are not equipped with the suitable technologies or having fuel of unsuitable contents or the price of clean fuel is more expensive than the electricity, the port offers this service option to customer.

Since cruise ships consume high volume of MGO to meet to necessary energy power while at ports, such ports hosting cruise ships have a serious negative impact on the quality of the country because of released emissions in their area, and they are known as bad neighbour. Use of cleaner fuels or technologies in such ports may in some cases lead to more costs for the shipowner, but will be indisputable method for human health and a cleaner environment in the future. When looking at the results for the Ege Ports, it is clear that there can be a significant decrease in emission reduction with AMP technology, these numbers can be further reduced compared to the source of electrical energy. If electricity is produced with cleaner sources, it is now possible to define eco-friendly ports for ships.

Moreover, the decline in the amount of these emissions is also beneficial to the environment, human health and ecosystem quality according to externality cost calculation and also proves to be beneficial to the country in terms of the economic outcome. Finally, AMP's most important difference from other alternative technologies and fuels is to reduce noise. It is especially very important for the touristic cities that have dense population.

Result of this study may guide to future studies on the installiton and running cost of AMP technology and how ship owners can decide to select a suitable alternative technology for their ships.

\section{References}

[1] Theodoros, P. G. (2012). A Cold Ironing Study on Modern Ports, Implementation and Benefits Thriving for Worldwide Ports, Thesis, School of Naval Architecture \& Marine Engineering National Technical University of Athens

[2] Pekşen, Y.D. (2016). Kruvaziyer Truziminin Çevreye Etkisinin Değerlendirilmesi; Kuşadası Kruvaziyer Limanı Örneği, International Multidisciplinary Congress of Eurasia, Odessa, 2016. 
[3] Chang, C. C., Wang, C. M. (2012). Evaluating the effects of green port policy: Case Study of Kaohsiung Harbor in Taiwan. Transportation Research Part D: Transport and Environment, 17(3), 185-189.

[4] Andria, G., Attivissimo,F., Cavone, G., Lanzolla A.M.L., Spadavecchia, M. (2013). Environmental Impact Assessment of the Marine Traffic In Port of Taranto: A Prelıminary Study, 4th Imeko TC19 Symposium on Environmental Instrumentation and Measurements Protecting Environment, Climate Changes and Pollution Control, June 3-4, 2013, Lecce, Italy,

[5] Ballini, F. (2013). Air Pollution from Ships in Danish Harbours: Feasibility Study of Cold-ironing Technology in Copenhagen, Department of Naval, Electrical, Electronic and Telecommunication Engineering, Ms.c University of Genoa, Italy 2013

[6] Zis, T., North, R.J., Angeloudis, P., Ochieng,W.Y, Bell , M.G.H. (2014). Evaluation of Cold Ironing and Speed Reduction Policies to Reduce Ship Emissions near and at Ports, Maritime Economics \& Logistics, 16(4), 371398

[7] Yustiano, O.Y. (2014). Cost and Benefit Analysis of Shore Side Electricity in the Port of Tanjung Perak, Indonesia, MS.c, World Maritime University, Sweden, 2014.

[8] Tseng, P., Pilcher, N. (2015). A Study of the Potential of Shore Power for the Port of Kaohsiung, Taiwan: to introduce or not to Introduce? Research in Transportation Business \& Management, 17 (2015) 83-91

[9] ENVIRON International Corporation Seaworthy Systems, Inc. (2015). Shoreside Power Feasibility Study for Cruise Ships Berthed at Port of San Francisco.
[10] ENTEC (2005). Service Contracton Ship Emissions: Assignment, Abatement and Market-based Instruments, Task 2a: The use of shore-side electricity, for the European Commission, DG Environment, Entec UK Ltd.

[11] Samosiri, D. H., Markert, M. and Busse, W. (2016). The Technical and Business Analysis of Using Shore Power Connection in The Port of Hamburg, Jurnal Teknik Its Vol. 5, No. 2, (2016) ISSN: 2337-3539 (2301-9271 Print)

[12] Tetra Tech (2007). Draft Use of ShoreSide Power For Ocean-Going Vessels White Paper.

[13] Deniz Ticareti Genel Müdürlüğü Kruvaziyer Turizmi İstatistikleri (2017) https://atlantis.udhb.gov.tr/ istatistik/istatistik_kruvaziyer.aspx

[14] Sezer, İ. (2014). Kruvaziyer Turizmi'nde dikkat çeken bir nokta: Kușadası Limanı. Doğu Coğrafya Dergisi - 32.

[15] Görgün, E. (2011). Geleceğin turizm anlayışında kruvaziyer turizm uygulamaları. Trakya Üniversitesi Sosyal Bilimler Enstitüsü İşletme Anabilim Dalı Yüksek Lisans Dönem Projesi, Edirne.

[16] Kuşadası Ticaret Odası (2011). Dünyada ve Türkiye'de kruvaziyer turizmi ve Kuşadası Limanı. Kuşadası.

[17] Marine Traffic http://www. marinetraffic.com/tr/ais/index/ ships/all

[18] Kuşadası Kaymakamlığı, (2015). Retrieved from http: /kusadasi.gov.tr/ marina

[19] Simonsen, M. (2014). Cruise Ship Tourism. A LCA Analysis, Western Norway Research Institution.

[20] Peksen, N. H. (2013). A New Approach for Turkish Ports to Reduce Ship Emissions Case Study: Application of Cold Ironing System for Marport Container Terminal with Investment Analysis, MS.c, World Maritime University. 
[21] Cai, H., Han, J., Wang, M. and Elgowainy, A. (2012). Updated Greenhouse Gas and Criteria Air Pollutant Emission Factors and Their Probability Distribution for Electric Generating Units, Argonne National Laboratory, Energy Systems Divisions, ANL/ ESD/12-2, May 2012, USA.Pg:31-33. Retrieved from http://www.epa.gov/ ttnchie1/conference/ei20/session8/ hcai.pdf

[22] TEİAȘ (2016). http://www.emo.org. tr/ekler/18ff249800ead7f_ek.pdf

[23] EXIOPOL (2011). A New Environmental Accounting Framework Using Externality Data And Input-Output Tools For Policy Analysis, Final report providing external cost values to be applied in an EE SUT framework, March 2010, PROJECT N. 037033, pg: 57. 